\title{
DESIGNING CRITICAL THINKING COMPETENCY FRAMEWORK AND EVALUATION TOOLKIT FOR STUDENTS THROUGH TEACHING IN HIGH SCHOOL
}

\author{
Nguyen Thị My Linh ${ }^{1}$ and Huynh Gia Bao ${ }^{2}$ \\ ${ }^{1}$ Chemistry team, Go Cong High School, Tien Giang province, Vietnam \\ ${ }^{2}$ Faculty of Pedagogy, Dong A University, Vietnam
}

https://doi.org/10.54922/IJEHSS.2022.0358

\begin{abstract}
Critical thinking in general and critical thinking capacity in particular is one of the essential thinking activities that need to be developed for students from elementary school to university. Competency framework for critical thinking plays an important role in teaching to train and develop this capacity for university students. It makes sense for lecturers in building competency assessment tools. This article presents the process of designing critical thinking competency framework and evaluation toolkit for students through chemistry teaching in high school.
\end{abstract}

Key Words: Evaluation toolset, capacity structure, critical thinking capacity, student.

\section{INTRODUCTION}

Critical thinking is one of the manifestations of dialectical thinking, helping people to analyze and evaluate problems and phenomena from many different perspectives, helping to find truth and truth effectively. better (Phan Trong Ngo, 2003). The issue of training and developing critical thinking capacity for learners has been studied by many scientists around the world. Because, developing critical thinking capacity is one of the important requirements of the current "fundamental and comprehensive reform" of education. Accordingly, Critical thinking together with its characteristic basic skills are the basis, creating the foundation for the development of more complex forms of thinking, higher level creative thinking and critical thinking (Nguyen). Phuong Thao, 2010). In the study Critical thinking is interested by many researchers such as J. Dewey (1859-1952; USA) emphasized: The essence of Critical thinking is the active and comprehensive consideration of information before giving it. make assessments; The key factor in Critical Thinking is the capacity to reason (Le Tan Huynh Cam Giang, 2011). Author Robert J.Stemberg (1980), has identified the characteristic elements of critical thinking. In which the important skill of Critical Thinking is the skill of solving problems, skillfully and accurately processing information to make meaningful decisions and actions for life (Le Tan Huynh Cam). Giang, 2011). Robert J.Stembert also affirmed: Critical thinking has many components and skills, in which the characteristic skills of Critical Thinking are information processing, and problem solving (Robert H. Ennis, 2003). ). On that basis, the author A.Fisher (2001) listed and analyzed the concepts of Critical Thinking, affirmed the importance of TDPB, identified 6 stages of thinking and guided how to think. correct, comprehensive, and fair feedback. In the article "Teaching and practicing critical thinking skills for students", the author has identified the benefits of Critical 


\section{International Journal of Education Humanities and Social Science}

ISSN: 2582-0745

Vol. 5, No. 01; 2022

Thinking for learners, the students' awareness levels towards Critical Thinking. argue, propose some steps in teaching to train students' critical thinking (Bui Loan Thuy, 2012).

However, the current state of higher education shows that students' critical thinking and creative abilities have not received much attention.

Table 1. Results of the level of competence in teaching at Go Cong High School, Vietnam

\begin{tabular}{|c|c|c|c|c|c|c|c|}
\hline \multirow[t]{2}{*}{ General Abilities } & \multicolumn{4}{|c|}{ Usage level } & \multirow[t]{2}{*}{ TB } & \multirow[t]{2}{*}{$S D$} & \multirow[t]{2}{*}{$P$} \\
\hline & Frequently & sometimes & Rarely & Never & & & \\
\hline $\begin{array}{l}\text { Capcapacity to solve the } \\
\text { problem }\end{array}$ & 32 & 7 & 1 & 0 & 2.78 & 0.46 & $<0,001$ \\
\hline Cooperation capacity & 35 & 5 & 0 & 0 & 2.88 & 0.53 & $<0,001$ \\
\hline Creative capacity & 14 & 25 & 1 & 0 & 2.3 & 0.34 & $<0,001$ \\
\hline Critical thinking capacity & 1 & 39 & 0 & 0 & 2.0 & 0.33 & $<0,001$ \\
\hline
\end{tabular}

Theoretical issues of critical thinking capacity of learners have been studied extensively by the authors, but a framework of critical thinking competence has not been built for students in the general teaching process. The study of competency framework Critical thinking for students has a lot of theoretical and practical significance in developing criteria and toolkit for capacity assessment Critical thinking for students in accordance with development education goals. our country's capacity in the current period

\section{CONTENTS}

\subsection{Overview of critical thinking and critical thinking capacity in the classroom}

\subsubsection{Critical thinking}

According to John Dewey, critical thinking is "reflective thinking" and is defined as: "The active, ongoing, careful consideration of a belief, a scientific assumption that takes into account the arguments that support it, and further conclusions are aimed at". By Edward Glaser, Critical Thinking is an attitude of willingness to think critically about problems and topics that arise in one's personal life; is an understanding of investigative methods and reasoned inference; and some skills in applying those methods (Nguyen Phuong Thao, 2010). The term critical in the phrase critical thinking can be translated as critical or critical. According to (Le Tan Huynh Cam Giang, 2011): "Criticism is an action word that indicates what is not good, what is wrong, does not imply the meaning of evaluation". Meanwhile, critical has broader connotations than criticism, meaning making judgments 


\section{International Journal of Education Humanities and Social Science}

ISSN: 2582-0745

Vol. 5, No. 01; 2022

According to (Nguyen Thanh Thi, 2013), Critical thinking is defined by the following skills: listening and observing, questioning, analyzing, evaluating, comparing points of view, selfcorrection.

\subsubsection{Critical thinking capacity in teaching}

According to (Nguyen Phuong Thao, 2010), "Critical thinking capacity is the ability of people to evaluate, to show positive interaction of people about the world around them". Inheriting researches on critical thinking, we believe that: Critical thinking capacity is the ability to apply independent thinking and reflective thinking in analysis and evaluation., relate every aspect of an existing information with a positive skepticism for the problem posed, thereby clarifying and reaffirming the accuracy of the problem with convincing arguments.

Elements of Critical Thinking competence include:

+ Critical thinking skills: Tools to think, build logical, creative, systematic arguments

+ Expertise: The foundation for building solid arguments with a scientific belief.

+ Critical attitude: Being skeptical of science, yearning to verify one's own views, having the spirit of self-control, independent in thinking, self-regulating to approach the truth.

\subsubsection{The role of developing critical thinking capacity for students}

Critical thinking is a type of higher-order thinking, closely related to creative thinking. If creative thinking shows in the ability to create new things, critical thinking shows in knowing how to evaluate and verify those new things. Developing critical thinking is a condition for forming creative thinking for students, helping students to overcome stereotypes, habits and barriers of prejudice to discover new values in perception. Critical thinking makes students have more effective thinking skills, information processing, deep learning, and the ability to solve learning tasks well, so that they are always proactive and confident in their learning. study and life (Phan Trong Ngo, 2003).

In modern teaching, critical thinking will promote the active learning of students, make students more interested and enthusiastic about learning, because they themselves are built knowledge and skills yourself, not cramming. Modern critical thinking plays an important role in developing critical thinking for students, on the contrary, critical thinking will help teaching methods be implemented more effectively. Critical thinking enables students to recognize, properly understand and criticize the distortions in perception of themselves and others. From there, it allows them to re-examine themselves, strive to surpass themselves, assert themselves, form their own personality, be independent, self-reliant and creative. Those are very important factors of modern man (Nguyen Thi Hang Nga, 2016).

\subsection{Framework of critical thinking capacity for students in teaching chemistry}

\subsubsection{The process of building a framework of critical thinking competence}




\section{International Journal of Education Humanities and Social Science}

ISSN: 2582-0745

Vol. 5, No. 01; 2022

The critical thinking competency framework for students plays an important and meaningful role for both teachers in building the process of organizing teaching activities and rating scale. We proceed to build according to a 5 -step process:

Step 1: Identify the basis for building a critical thinking competency framework

Derived from domestic and international documents related to: Thinking, Critical thinking, Critical thinking capacity. We rely on the following arguments to ensure that the critical thinking competency framework of students is consistent with educational practice in Vietnam:

1. Resolution of the 9th Central Conference, term XII (NQ 29-NQ/TW).

2. Directive No. 16/CT-TTg (May 4, 2017) of the Prime Minister on strengthening access to the 4 Industrial Revolution

3. Directive of the Ministry of Education and Training No: 2268/CT-BGDĐT dated 8/8/2019: "On the tasks and solutions for the 2019-2020 school year of the Education sector".

4. Publicized works on competence in general and critical thinking capacity.

Step 2: Building a critical thinking competency framework (draft)

We propose a critical thinking competency framework (the former is the premise of developing the latter) including the following five component competencies: independent thinking, problemsolving, and reflective thinking.

After proposing the component capabilities, we proceed to define the criteria of each component capability. The Critical Thinking Competency Framework was originally designed to include 3 component competencies and 10 criteria

Step 3: Seek expert opinion on critical thinking competency framework (draft)

After completing the draft Critical Thinking competency framework, we send it to experts who are researchers in the fields of: Theory and methods of teaching chemistry and psychology in high schools.

After receiving feedback from experts, the draft Critical Thinking competency framework was revised and continued to be sent for consensus.

Step 4: Edit the critical thinking competency framework

Experts say that: "Thinking" should be replaced by "thinking", giving up the ability to solve problems because the ability to think reflectively can involve. After receiving feedback from experts, the draft critical thinking competency framework of students was revised to include 2 component competencies and 8 criteria with 3 levels of expression.

Step 5. Test and perfect the critical thinking competency framework 


\section{International Journal of Education Humanities and Social Science}

ISSN: 2582-0745

Vol. 5, No. 01; 2022

We tested the Critical Thinking competency framework for 4th grade students in 11th grade from Cho Gao High School, Go Cong High School to check the feasibility and objectivity of the scale and complete the framework. We propose a competency framework Critical thinking for students through teaching and learning chemistry, including 2 component competencies and 8 criteria (expression).

\subsubsection{Framework of students' critical thinking ability}

Competency framework Critical thinking of students is shown:

Table 2. Structure of critical thinking capacity of high school students

\begin{tabular}{|c|c|c|}
\hline $\mathrm{TT}$ & Component capacity & Expression of critical thinking capacity \\
\hline \multirow{4}{*}{1} & \multirow{4}{*}{ Independent thinking } & 1. Listen and observe \\
\hline & & 2. Collect information \\
\hline & & 3. Asking questions \\
\hline & & 4. Analyze, evaluate, compare opinions \\
\hline \multirow{4}{*}{2} & \multirow{4}{*}{ Reflective thinking } & 5. Problem solving \\
\hline & & 6. Concluded \\
\hline & & 7. Test results \\
\hline & & 8. Self-regulating \\
\hline
\end{tabular}

\subsubsection{The expression level of students' critical thinking ability criteria}

On the basis of the students' critical thinking competency framework, we describe the expression level of 8 criteria through 3 levels as follows:

Level 1. Average level: Students show their ability not often. Needs to be further developed Level 2. Good level: Students show their ability quite often but not yet actively and need to be promoted

Level 3. Good level: Students show their ability regularly and positively. Should be maintained. 


\section{International Journal of Education Humanities and Social Science}

ISSN: 2582-0745

Vol. 5, No. 01; 2022

Table 3. Table describing the expression levels of the criteria of critical thinking capacity

\begin{tabular}{|c|c|c|c|}
\hline Component of & Criteria & & xpression level of the criteria of critical thinking capacity \\
\hline \multirow{12}{*}{$\begin{array}{l}\text { Independent } \\
\text { thinking }\end{array}$} & \multirow{3}{*}{$\begin{array}{l}\text { Listen and } \\
\text { observe }\end{array}$} & $L_{1}$ & The first step is to receive the information \\
\hline & & $L_{2}$ & Receiving information selectively \\
\hline & & $L_{3}$ & Receive and respond to information selectively \\
\hline & \multirow{3}{*}{$\begin{array}{c}\text { Collect } \\
\text { information }\end{array}$} & $L_{1}$ & Collect non-selective information \\
\hline & & $L_{2}$ & Collect information selectively \\
\hline & & $L_{3}$ & Collect and analyze information critically. \\
\hline & \multirow[t]{3}{*}{$\begin{array}{l}\text { Asking } \\
\text { questions }\end{array}$} & $L_{1}$ & $\begin{array}{l}\text { Asking questions, but some of them are not suitable for } \\
\text { the collected information }\end{array}$ \\
\hline & & $L_{2}$ & $\begin{array}{l}\text { Ask questions that are appropriate to the information } \\
\text { collected }\end{array}$ \\
\hline & & $L_{3}$ & $\begin{array}{l}\text { Ask the right, necessary questions and express them with } \\
\text { clarity }\end{array}$ \\
\hline & \multirow{3}{*}{$\begin{array}{l}\text { Analyze, } \\
\text { evaluate, } \\
\text { compare } \\
\text { opinions }\end{array}$} & $L_{1}$ & Analyze relationships, causes, goals, structures... \\
\hline & & $L_{2}$ & $\begin{array}{l}\text { Be able to compare one object against another, based on } \\
\text { a certain criterion }\end{array}$ \\
\hline & & $L_{3}$ & $\begin{array}{l}\text { Make judgments, opinions, suggestions about a } \\
\text { phenomenon, an event, situation, result ... based on } \\
\text { specific evidences }\end{array}$ \\
\hline \multirow{5}{*}{ Reflective thinking } & \multirow{3}{*}{$\begin{array}{l}\text { Problem } \\
\text { solving }\end{array}$} & $L_{1}$ & Suggested solutions but not suitable \\
\hline & & $L_{2}$ & $\begin{array}{l}\text { Proposing appropriate solutions based on knowledge } \\
\text { application }\end{array}$ \\
\hline & & $L_{3}$ & $\begin{array}{l}\text { Proposing appropriate solutions on the basis of applying } \\
\text { knowledge and personal life experiences. }\end{array}$ \\
\hline & \multirow[t]{2}{*}{ Concluded } & $L_{1}$ & Synthesize unconvincing opinions and arguments \\
\hline & & $L_{2}$ & Synthesize points of view, argue with persuasive \\
\hline
\end{tabular}




\section{International Journal of Education Humanities and Social Science}

ISSN: 2582-0745

Vol. 5, No. 01; 2022

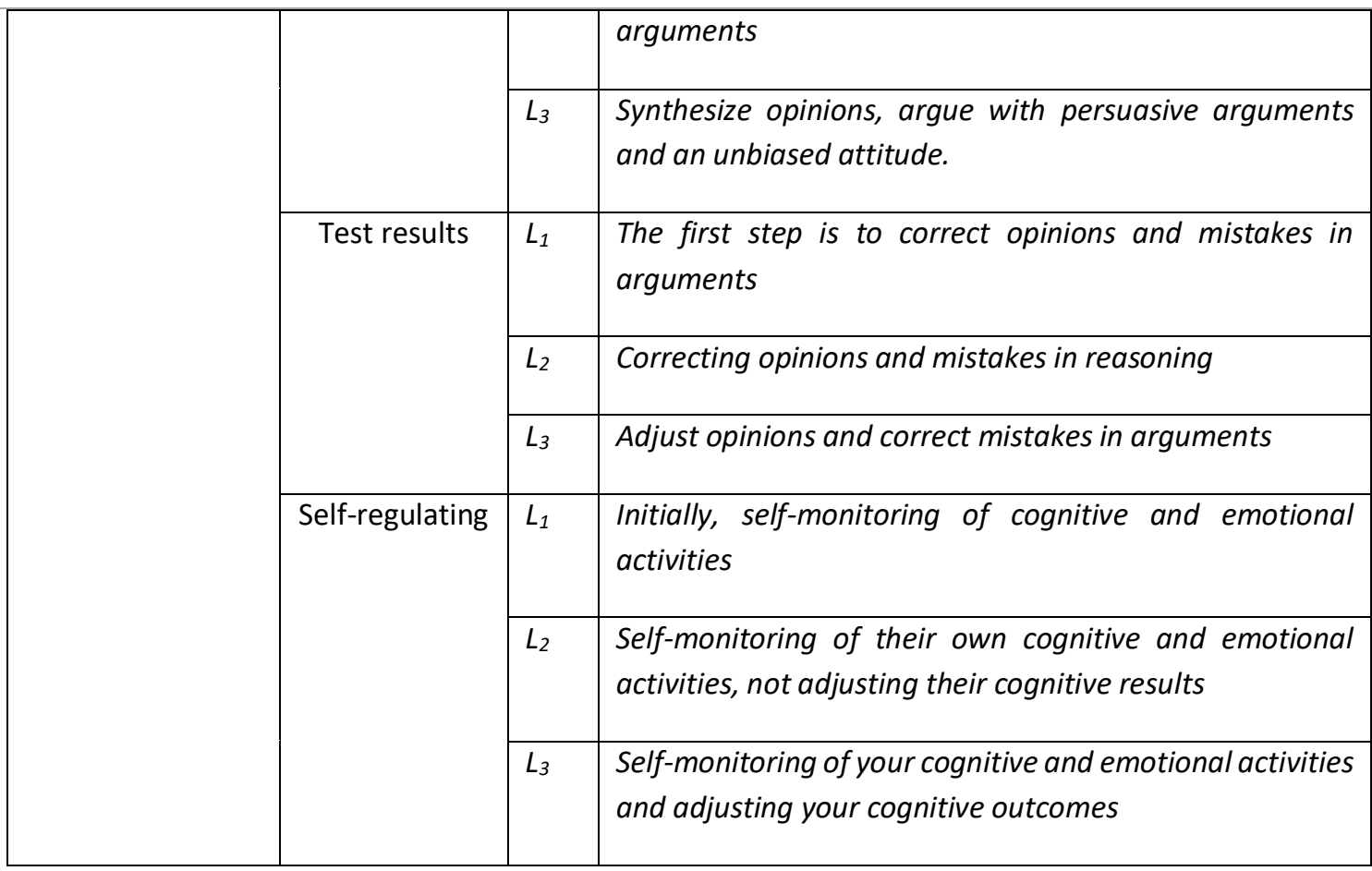

2.3. Tools for developing students' critical thinking ability in teaching

Based on the critical thinking competency framework, we have built the criteria table and the assessment sheet for students' critical thinking ability.

\section{Table 4. Table of criteria for assessing critical thinking capacity}

\begin{tabular}{|c|c|c|c|}
\hline \multirow[t]{2}{*}{ Criteria } & \multicolumn{3}{|c|}{ Level of expression of criteria } \\
\hline & 1 & 2 & 3 \\
\hline $\begin{array}{l}\text { 1. Listen and } \\
\text { observe }\end{array}$ & $\begin{array}{l}\text { The first step is to } \\
\text { receive the information }\end{array}$ & $\begin{array}{l}\text { Receiving information } \\
\text { selectively }\end{array}$ & $\begin{array}{l}\text { Receive and respond to } \\
\text { information selectively }\end{array}$ \\
\hline $\begin{array}{l}\text { 2. Collect } \\
\text { information }\end{array}$ & $\begin{array}{l}\text { Collect non-selective } \\
\text { information }\end{array}$ & $\begin{array}{l}\text { Collect } \\
\text { selectively }\end{array}$ & $\begin{array}{l}\text { Collect and analyze information } \\
\text { critically. }\end{array}$ \\
\hline 3. Asking questions & $\begin{array}{l}\text { Asking questions, but } \\
\text { some of them are not } \\
\text { suitable for the }\end{array}$ & $\begin{array}{l}\text { Ask questions that are } \\
\text { appropriate to the } \\
\text { information collected }\end{array}$ & $\begin{array}{l}\text { Ask the right, necessary } \\
\text { questions and express them } \\
\text { with clarity }\end{array}$ \\
\hline
\end{tabular}




\section{International Journal of Education Humanities and Social Science}

ISSN: 2582-0745

Vol. 5, No. 01; 2022

\begin{tabular}{|c|c|c|c|}
\hline & collected information & & \\
\hline $\begin{array}{c}\text { 4. Analyze, } \\
\text { evaluate, compare } \\
\text { opinions }\end{array}$ & $\begin{array}{lr}\text { Analyze relationships, } \\
\text { causes, } \\
\text { structures... }\end{array}$ & $\begin{array}{l}\text { Be able to compare one } \\
\text { object against another, } \\
\text { based on a certain criterion }\end{array}$ & $\begin{array}{l}\text { Make judgments, opinions, } \\
\text { suggestions about a } \\
\text { phenomenon, an event, } \\
\text { situation, result ... based on } \\
\text { specific evidences }\end{array}$ \\
\hline 5. Problem solving & $\begin{array}{l}\text { Suggested solutions but } \\
\text { not suitable }\end{array}$ & $\begin{array}{l}\text { Proposing appropriate } \\
\text { solutions based on } \\
\text { knowledge application }\end{array}$ & $\begin{array}{l}\text { Proposing appropriate solutions } \\
\text { on the basis of applying } \\
\text { knowledge and personal life } \\
\text { experiences. }\end{array}$ \\
\hline 6. Concluded & $\begin{array}{l}\text { Synthesize } \\
\text { unconvincing opinions } \\
\text { and arguments }\end{array}$ & $\begin{array}{l}\text { Synthesize points of view, } \\
\text { argue with persuasive } \\
\text { arguments }\end{array}$ & $\begin{array}{l}\text { Synthesize opinions, argue with } \\
\text { persuasive arguments and an } \\
\text { unbiased attitude. }\end{array}$ \\
\hline 7. Test results & $\begin{array}{l}\text { The first step is to } \\
\text { correct opinions and } \\
\text { mistakes in arguments }\end{array}$ & $\begin{array}{l}\text { Correcting opinions and } \\
\text { mistakes in reasoning }\end{array}$ & $\begin{array}{l}\text { Adjust opinions and correct } \\
\text { mistakes in arguments }\end{array}$ \\
\hline 8. Self-regulating & $\begin{array}{l}\text { Initially, self- } \\
\text { monitoring of cognitive } \\
\text { and } \\
\text { activities }\end{array}$ & $\begin{array}{l}\text { Self-monitoring of their } \\
\text { own cognitive and } \\
\text { emotional activities, not } \\
\text { adjusting their cognitive } \\
\text { results }\end{array}$ & $\begin{array}{l}\text { Self-monitoring of your } \\
\text { cognitive and emotional } \\
\text { activities and adjusting your } \\
\text { cognitive outcomes }\end{array}$ \\
\hline
\end{tabular}

\section{Table 5. Assessment sheet for students' critical thinking ability}

\section{High School:}

2. Student:

3. Class:

\begin{tabular}{|c|l|l|l|}
\hline Component capacity & \multicolumn{1}{|c|}{ Criteria } & Point & Total score \\
\hline \multirow{4}{*}{ Independent thinking } & 1. Listen and observe & & \multirow{2}{*}{} \\
\cline { 2 - 3 } & 2. Collect information & & \\
\cline { 2 - 3 } & 3. Asking questions & & \\
\cline { 2 - 3 } & 4. Analyze, evaluate, compare opinions & & \\
\hline Reflective thinking & 5. Problem solving & & \\
\hline
\end{tabular}




\section{International Journal of Education Humanities and Social Science}

ISSN: 2582-0745

Vol. 5, No. 01; 2022

\begin{tabular}{|r|l|l|l|}
\hline & 6. Concluded & & \\
\cline { 2 - 3 } & 7. Test results & & \\
\cline { 2 - 3 } & 8. Self-regulating & & \\
\hline \multicolumn{2}{|c|}{ Tổng cộng } & \\
\hline
\end{tabular}

\subsection{Teacher poll results on critical thinking competency framework}

To check the appropriateness of the component competencies, criteria, and assessment levels, we conducted a survey of chemistry teachers who are directly teaching chemistry at high schools:

In survey questions, the criteria are coded as follows: "Strongly suitable/Strongly agree" $=3$, "Suitable/Agree" = 2, "Not suitable/Disagree" = 1, The data on mean (TB), standard deviation (SD) and T-test $(\mathrm{P})$ are processed by SPSS software for calculation.

Table 7. Relevance of the component competencies of critical thinking ability

\begin{tabular}{|r|c|c|c|c|c|c|c|}
\hline \multirow{2}{*}{ Component capacity } & \multicolumn{3}{|c|}{ Usage level } & TB & SD & P \\
\cline { 2 - 8 } & Very suitable & Suitable & Not suitable & & & & \\
\hline Independent thinking & 32 & 7 & 1 & 2.78 & 0.46 & & $<0,001$ \\
\hline Reflective thinking & 35 & 5 & 0 & 2.88 & 0.53 & & $<0,001$ \\
\hline
\end{tabular}

Table 8. Level of agreement with the criteria of critical thinking ability

\begin{tabular}{|c|c|c|c|}
\hline \multirow[t]{2}{*}{ Level } & Strongly agree & Agree & Disagree \\
\hline & $13(32.5 \%)$ & $27(67.5 \%)$ & $0(0 \%)$ \\
\hline$T B$ & & 2,42 & \\
\hline$S D$ & & 0.43 & \\
\hline $\boldsymbol{P}$ & & $<0,001$ & \\
\hline
\end{tabular}

The survey results showed that the majority of teachers participating in the survey agreed with the components of competence and criteria (expression). That shows that the critical thinking competency framework of students built is appropriate and feasible. 


\section{International Journal of Education Humanities and Social Science}

ISSN: 2582-0745

Vol. 5, No. 01; 2022

\section{CONCLUSION}

Through the process of building a critical thinking competency framework for students in teaching at high schools, we have received positive feedback from education experts. Competency framework Critical thinking for students is built with 2 component competencies with 8 specific criteria used to develop a process of organizing teaching activities and a table of criteria for assessing competence Critical thinking for HS. Experimental evaluation results used in teaching have given reliable results, which have the effect of promoting students to develop critical thinking capacity.

\section{REFERENCES}

1.Phan Trong Ngo (editor, 2003), Theories of human psychological development, Pedagogical University Publishing House.

2.Nguyen Phuong Thao (2010), Developing critical thinking for students through dialogue in teaching Mathematics in high schools. Thesis of Doctor of Education, Hanoi University of Education.

3.Le Tan Huynh Cam Giang (2011), "Understanding Critical Thinking”, Educational Research Institute, Ho Chi Minh University of Education

4.Robert H. Ennis (2003), Critical thinking Assessment, Critical thinking Assesmen Theory into Practice Number 3

5.Bui Loan Thuy (2012), "Teaching and practicing critical thinking skills for students", Journal of Development and Integration, p. 76 - 81.

6Nguyen Thanh Thi (2013), "Need to train students' critical learning ability", Journal of Culture and Tourism, p.67.

7.Ministry of Education and Training (2018), General education program - Master program.

8.Prime Minister (2017),

9.Directive No. 16/CT-TTg (May 4, 2017) of the Prime Minister on strengthening access to the Fourth Industrial Revolution.

10.Ministry of Education and Training (2018), Directive of the Ministry of Education and Training No: 2268/CT-BGDĐT dated August 8, 2019: "On the tasks and solutions for the 2019-2020 school year of the Education sector"

11.Nguyen Thi Hang Nga (2016), Developing students' critical thinking capacity with Math exercises in teaching the 12th grade biological genetics at high school, Doctoral thesis in education, Hanoi PP and high school . 